\title{
Meningkatkan hasil belajar dan kemandirian peserta didik dengan menggunakan media pembelajaran mobile learning berbasis ispring suite 9
}

\author{
Gita Chandra Asmaradhana, Madziatul Churiyah* \\ Universitas Negeri Malang, Jl. Semarang No. 5 Malang, Jawa Timur, Indonesia \\ *Penulis korespondensi, Surel: madziatul.churiyah.fe@um.ac.id
}

Paper received: 3-3-2021; revised: 24-3-2021; accepted: 28-3-2021

\begin{abstract}
Abstrak
Berdasarkan kondisi dan fenomena tahun ini pendidikan di Indonesia sedang mengalami perubahan besar dimana sejak akhir tahun 2019 Coronavirus Disease (Covid-19) telah terjadi masalah kesehatan dan berpengaruh terhadap kebijakan pendidikan. Kebijakan tersebut menyatakan bahwa proses belajar mengajar dilaksanakan dirumah melalui pembelajaran daring/jarak jauh sampai batas waktu yang belum diketahui. Seluruh aspek dituntut untuk bisa beradaptasi dengan keadaan tersebut, dimana pedidik dan peserta didik tidak bertemu secara langsung akan tetapi terkoneksi melalui media yang terintegrasi dengan internet. Berkaitan dengan hal tersebut, maka penelitian ini bertujuan untuk menghasilkan produk media pembelajaran mobile learning berbasis Ispring suite 9 agar dapat menjadi alternatif pilihan media pembelajaran, penelitian dan pengembangan ini menggunakan model Research and Development Borg and Gall yang telah dimodifikasi, Teknik analisis data yang digunakan adalah deskriptif persentase dan uji paired sample t-test. Hasil penelitian dan pengembangan ini menunjukan bahwa media pembelajaran berbasis ispring suite 9 pada mata pelajaran otomatisasi tata kelola humas dan keprotokolan yang bernama el-PR (Elektronik Learning Public Relation) dinyatakan sangat valid dan layak digunakan berdasarkan penilaian dari ahli media, ahli materi dan 6 peserta didik uji coba kelompok kecil serta terbukti dapat meningkatkan kemandirian belajar dan hasil belajar peserta didik secara signifikan pada uji coba kelompok besar. Sehingga dapat disimpulkan bahwa el-PR layak dan efektif digunakan sebagai media pembelajaran untuk meningkatkan kemandirian belajar dan hasil belajar peserta didik pada mata pelajaran otomatisasi tata kelola humas dan keprotokolan.
\end{abstract}

Kata kunci: media pembelajaran; ispring suite 9; otomatisasi tata kelola humas dan keprotokolan; hasil belajar; kemandirian belajar.

\section{Pendahuluan}

Berdasarkan Surat Edaran (SE) yang dikeluarkan pemerintah Indonesia pada tanggal 24 maret 2020 Menteri Pendidikan dan Kebudayaan Republik Indonesia mengeluarkan Surat Edaran (SE) Nomor 4 tahun 2020 Tentang Pelaksanaan Kebijakan Pendidikan dalam Masa Darurat Penyebaran Covid-19. Dijelaskan dalam surat edaran tersebut bahwa proses belajar dilaksanakan di rumah melalui pembelajaran daring/jarak jauh. Oleh karena itu, dunia pendidikan perlu memanfaatkan kemajuan teknologi dengan melakukan pengembangan media pembelajaran yang diharapkan dapat membantu serta menunjang proses pembelajaran yang lebih baik khususnya pada masa pandemi Covid-19. Media pembelajaran sendiri memegang peran penting dalam proses pembelajaran dimana media pembelajaran mampu membantu guru dalam menyampaikan materi yang diajarkan (Greene dkk., 2020), (Kramer dkk., 2020), (Sholihin dkk., 2020), (Ramdhani \& Muhammadiyah, 2015). Selain itu, penggunaan media pembelajaran juga diharapkan mampu meningkatkan pemahaman peserta didik terkait materi yang diajarkan oleh guru (Wijaya dkk., 2020), (Siregar dkk., 2020), (Fajriah \& Churiyah, 2016), (Yang dkk., 2012)

This work is licensed under a Creative Commons Attribution-ShareAlike 4.0 International License. 
Beberapa penelitian sebelumnya juga telah membuktikan bahwa media pembelajaran mampu meningkatkan hasil belajar, kemandirian belajar dan efektif memaksimalkan pemahaman konseptual peserta didik. (Yeldham \& Gao, 2020), (Ariyanti dkk., 2020), (Sari and Ridwan, 2020), (Sahronih dkk., 2019), (Nudiya dkk., 2019), (Rafiq, 2017), (Himmah, 2017). Media pembelajaran yang dimaksud dalam penelitian-penelitian tersebut adalah media pembelajaran berbasis ispring suite, dimana media pembelajaran tersebut efektif dan tepat digunakan untuk proses pembelajaran jarak jauh. (Wang dkk., 2020), (Arulogun dkk., 2020), (Kumar dkk., 2019), (Herbst \& Chazan, 2015). Media pembelajaran dengan konsep Pembelajaran Jarak Jauh harus dapat dilakukan secara daring atau tidak tatap muka. (Azzahra, 2020), (Deng dkk., 2020). Pembelajaran jarak jauh harus mampu memfasilitasi peserta didik untuk belajar secara mandiri dan memahamkan materi ajar ke peserta didik. (Kusuma dkk., 2020), (Kusumarini \& Bangunan, 2020), (Bali, 2019). Kegiatan pembelajaran menggunakan media pembelajaran berbasis ispring suite 9 juga fleksibel karena peserta didik dapat mengakses dan melakukan pembelajaran kapanpun dan dimanapun berada, karena harus disesuaikan dengan keterbatasan waktu peserta didik dengan pendidiknya. (pohan, 2020), (Kusumarini \& Bangunan, 2020), (Fitri, 2020), (Hussein dkk., 2020), (Panigrahi dkk., 2018). Sehingga dapat disimpulkan bahwa media ini sangat cocok digunakan sebagai inovasi kegiatan pembelajaran sebelum, saat dan sesudah pandemi Covid-19 berakhir. (Sufian dkk., 2020) , (Qazi dkk., 2020) (Parsazadeh dkk., 2018).

Akan tetapi, berdasarkan hasil observasi dan wawancara dengan guru di SMK PGRI 2 Malang pada 4 september 2020 diperoleh informasi bahwa hasil belajar peserta didik pada mata pelajaran Otomatisasi Tata Kelola Humas dan Keprotokolan masih kurang dan perlu ditingkatkan. Dimana sejak maret 2020 proses belajar mengajar dilakukan melalui platform online yaitu google classroom dan mengingat tidak semua lokasi peserta didik memiliki jaringan internet yang mewadahi serta kuota internet yang mencukupi maka berdasarkan pengamatan terdapat peserta didik yang terlambat dalam mengakses materi pembelajaran serta saat melakukan pengumpulan tugas yang diberikan. Oleh karena itu, penelitian ini bertujuan untuk menghasilkan produk media pembelajaran berbasis ispring suite 9 secara offline yang teruji kelayakan dan keefektifan dalam meningkatkan hasil belajar dan kemandirian peserta didik kelas XI pada mata pelajaran Otomatisasi Tata Kelola Perkantoran Humas dan Keprotokolan di SMK PGRI 2 Malang.

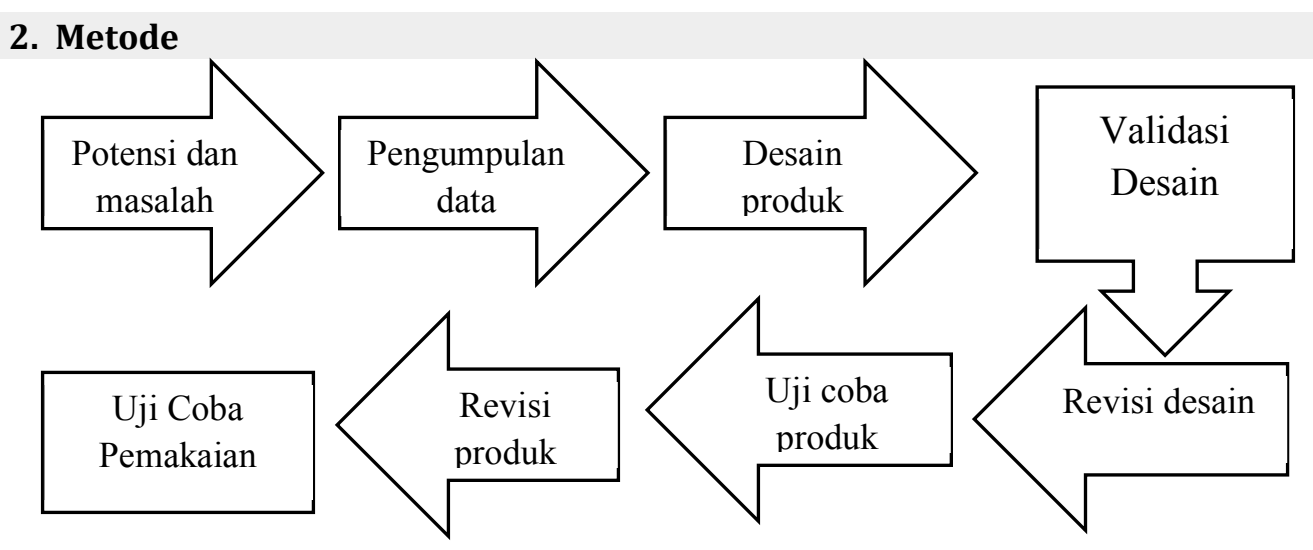

Gambar 1 Langkah-langkah Penelitian 
Penelitian ini menggunakan model Research and Development Borg and Gall yang telah dimodifikasi menjadi delapan langkah untuk mempersingkat waktu dan meminimalisir biaya (Suparti, 2016:64). Selain itu, peneliti juga memiliki tujuan penelitian yaitu untuk menghasilkan produk mengetahui kelayakan produk dan mengetahui perbedaan hasil belajar serta kemandirian sebelum dan sesudah menggunakan produk yang dikembangkan. Langkah pertama, peneliti mengumpulkan informasi terkait potensi dan permasalahan yang terjadi di sekolah melalui tahap observasi dan wawancara. Langkah kedua, peneliti mulai merancang produk media pembelajaran yang akan dikembangkan dan disesuaikan dengan kondisi serta kebutuhan untuk mengatasi permasalahan yang ditemukan pada langkah pengumpulan informasi awal. Langkah ketiga, peneliti mulai membuat media pembelajaran sesuai dengan rancangan yang telah ditentukan pada langkah sebelumnya. Langkah keempat yaitu setelah media tersebut dihasilkan maka dilakukan pengujian kelayakan oleh validator, yakni satu ahli media dan satu ahli materi. Langkah kelima, produk yang telah divalidasi direvisi berdasarkan kritik dan saran baik secara tertulis maupun lisan yang tertera pada lembar kuesioner ahli media dan materi. Langkah keenam, produk yang telah direvisi diuji cobakan pada 6 peserta didik kelas XI OTP data ini digunakan untuk memperbaiki atau merevisi media yang dikembangkan sebelum diuji cobakan kepada kelompok besar. Langkah ketujuh, produk yang telah diuji cobakan pada kelompok kecil direvisi sesuai kritik dan saran baik secara tertulis maupun lisan yang tertera pada lembar kuesioner penilaian peserta didik uji coba kelompok kecil. Langkah kedelapan, produk yang telah direvisi dan dinyatakan layak kemudian diuji cobakan pada kelompok besar. Uji coba ini tidak menggunakan kelas kontrol karena keterbatasan jumlah kelas di SMK PGRI 2 Malang sehingga hanya memakai 1 kelas yang melibatkan 30 peserta didik yang sedang menempuh mata pelajaran Otomatisasi Tata Kelola Humas dan Keprotokolan. Produk yang telah melewati uji coba kelompok besar menjadi produk akhir dalam penelitian ini.

Data yang dihasilkan pada penelitian dan pengembangan ini meliputi data kuantitatif dan data kualitatif, dimana data kuantitatif didapatkan melalui hasil penilaian validasi ahli materi, hasil validasi media, data hasil uji coba kelompok kecil, data hasil kemandirian belajar dan data hasil belajar peserta didik. Data Hasil hasil penilaian validasi ahli materi, hasil validasi media, data hasil uji coba kelompok kecil dianalisis menggunakan metode deskriptif persentase berbantuan excel untuk menunjukan tingkat kelayakan media pembelajaran, sedangkan analisis penelitian pada uji coba kelompok besar menggunakan desain eksperimen one group pretest-posttest dan setelah data didapatkan data Kemandirian belajar dan hasil belajar dianalisis menggunakan uji paired sample t-test berbantuan SPSS 23.0 untuk menunjukan perbedaan kemandirian belajar dan hasil belajar sebelum dan sesudah menggunakan media pembelajaran yang dikembangkan. Data kualitatif pada penelitian ini didapatkan melalui penarikan kesimpulan berdasarkan pendapat secara umum, saran dan kritik dari ahli media, ahli materi dan 6 peserta didik pada uji coba kelompok kecil.

\section{Hasil dan Pembahasan}

Produk yang dihasilkan dalam penelitian dan pengembangan ini adalah media pembelajaran berbasis ispring suite 9 pada mata pelajaran Otomatisasi Tata Kelola Humas dan Keprotokolan bernama el-PR (electronic learning public relation) yang tersedia secara gratis pada link shorturl.at/ny/BW2. Aplikasi el-PR secara garis besar terdiri dari tombol menu dan ikon yang dijelaskan melalui gambar 2 
Jurnal Ekonomi, Bisnis dan Pendidikan, 1(3), 2021, 251-262

Ikon pengembang. Berisikan profil, informasi dan kontak pengembang.

Ikon daftar rujukan. Berisikan berbagai sumber atau rujukan dari isi materi pembelajaran yang digunakan pada materi

Menu Evaluasi. Membantu peserta didik dalam mengerjakan latihan soal pada KD 3.1 sampai KD 3.4 mata pelajaran Humas dan Keprotokolan Kelas XI OTK

Ikon Home berfungsi sebagai tools untuk mengembalikan aplikasi ke menu dashboard.

Ikon Panah berfungsi untuk memindahkan halaman satu kehalaman lainnya atau sebaliknya.

Menu Kompetensi. Menampilkan cangkupan Kompetensi Inti (KI) dan Kompetensi Dasar (KD) OTP Humas dan Keprotokolan kelas XI.

Menu Materi. Menampilkan materi dalam bentuk tulisan dan video pada KD 3.1 sampai KD 3.4 mata pelajaran OTP Humas dan Keprotokolan kelas XI OTP

Menu Evaluasi. Membantu peserta didik dalam mengerjakan latihan soal pada KD 3.1 sampai KD 3.4 mata pelajaran Humas dan Keprotokolan Kelas XI OTK

Menu laporkan hasil. Berisikan pilihan untuk mengirimkan hasil evalusi (nilai) kepada guru melalui link menuju Whatsapp.

\section{Gambar 2 Menu-menu dalam aplikasi el-PR (electronic learning Public Relation)}

Hasil validasi aplikasi el-PR oleh ahli media, ahli materi dan 6 peserta didik kelompok kecil secara keseluruhan disajikan pada Tabel 1 berikut ini:

Tabel 1 Hasil Keseluruhan Validasi dan Uji Coba Kelompok Kecil

\begin{tabular}{llll}
\hline No & Validasi & Persentase & Kriteria Validitas \\
\hline 1 & Ahli Media & $92,23 \%$ & Sangat Valid \\
2 & Ahli Materi & $98,67 \%$ & Sangat Valid \\
3 & Uji Coba Penggunaan pada & $95 \%$ & Sangat Valid \\
& Kelompok Kecil & & \\
Rata-Rata & $95,30 \%$ & Sangat Valid \\
\hline
\end{tabular}

Table used by permission Asmaradhana, Gita Chandra. 2020. DataHasilvalidasi keseluruhan

Berdasarkan Tabel 1, diketahui rata-rata persentase validasi keseluruhan sebesar 95,30\% sehingga dapat disimpulkan bahwa media pembelajaran el-PR dinyatakan "sangat valid" dan layak digunakan untuk pembelajaran pada mata pelajaran Otomatisasi Tata Kelola Humas dan Keprotokolan Kelas XI di SMK PGRI 2 Malang. Hal ini senada dengan penelitian 
sebelumnya dimana hasil validasi ahli media, ahli materi dan uji coba kelompok kecil sebagai dasar penentuan kelayakan media. (Ariyanti dkk., 2020), (Sari \& Ridwan, 2020), (Dasmo dkk., 2020), (Himmah, 2017), (Yektyastuti \& Ikhsan, 2016)

Kelayakan tersebut terletak pada keunikan aplikasi el-PR yaitu user interfriendly dimana aplikasi ini dirancang didesain secara responsive, kontras warna yang baik dan dapat digunakan secara mudah. Hal ini juga selaras oleh (Damayanti dkk., 2018) yang mengatakan bahwa ispring suite merupakan media pembelajaran yang praktis dan bervariasi sehingga media ini efektif untuk digunakan. Keunikan yang kedua yaitu media ini memenuhi requirement serta mendukung otomatisasi yang disesuaikan dengan berbagai perangkat agar pengguna mudah dan nyaman menggunakan aplikasi el-PR karena didalamnya sudah berisi macam-macam bentuk pengemasan materi yang berbeda, Sejalan dengan (Alfiyansah, 2016) mengatakan bahwa ispring dikembangkan untuk mendukung e-learning juga dapat menyisipkan berbagai bentuk media sehingga media pembelajaran yang dihasilkan menarik, mudah didistribusikan dalam bentuk format flash yang dapat digunakan dimanapun dan dioptimalkan untuk smartphone.

Uji coba yang dilakukan yaitu dengan melibatkan satu kelas sampel dan analisis tes yang digunakan yaitu desain eksperimen one group pretest-posttest. Adapun pola penelitian metode one group pretest-posttest design menurut (Arikunto, 2010) sebagai berikut

\section{$\mathrm{O}_{1} \times \mathrm{O}_{2}$}

Gambar 3. Metode one Group pre-test posttest

(Sumber: Arikunto, (2010:85))

$\mathrm{O}_{1}=$ Nilai pretest (Sebelum menggunakan mobile learning, menggunakan google classxroom)

$\mathrm{X}=$ Penerapan Mobile Learning (el-PR)

$\mathrm{O}_{2}=$ Nilai posttest (Sesudah menggunakan mobile learning el-PR)

Sedangkan untuk hasil analisis data kuesioner kemandirian belajar sebelum dan sesudah menggunakan aplikasi yang dikembangkan disajikan pada Tabel 2

Tabel 2 Data Hasil Persentase tiap aspek kemandirian

\begin{tabular}{|c|c|c|c|c|c|}
\hline \multirow{2}{*}{ Aspek } & \multicolumn{3}{|c|}{ Perlakuan } & \multicolumn{2}{|r|}{$\begin{array}{l}\text { Rata- } \\
\text { rata }\end{array}$} \\
\hline & $\begin{array}{l}\text { Kemandirian } \\
\text { sebelum }\end{array}$ & Kategori & $\begin{array}{l}\text { Kemandirian } \\
\text { sesudah }\end{array}$ & Kategori & \\
\hline Evaluasi Diri & $65 \%$ & $\begin{array}{l}\text { Cukup } \\
\text { Mandiri }\end{array}$ & $87 \%$ & Mandiri & $76 \%$ \\
\hline $\begin{array}{l}\text { Menetapkan } \\
\text { Tujuan dan } \\
\text { Prencanaan }\end{array}$ & $74 \%$ & Mandiri & $92 \%$ & $\begin{array}{l}\text { Sangat } \\
\text { Mandiri }\end{array}$ & $83 \%$ \\
\hline $\begin{array}{l}\text { Mencari } \\
\text { informasi }\end{array}$ & $67 \%$ & $\begin{array}{l}\text { Cukup } \\
\text { Mandiri }\end{array}$ & $96 \%$ & $\begin{array}{l}\text { Sangat } \\
\text { Mandiri }\end{array}$ & $82 \%$ \\
\hline $\begin{array}{l}\text { Mengatur } \\
\text { Lingkungan }\end{array}$ & $73 \%$ & Mandiri & $90 \%$ & $\begin{array}{l}\text { Sangat } \\
\text { Mandiri }\end{array}$ & $81 \%$ \\
\hline $\begin{array}{l}\text { Konsekuensi } \\
\text { Diri }\end{array}$ & $58 \%$ & $\begin{array}{l}\text { Kurang } \\
\text { Mandiri }\end{array}$ & $90 \%$ & $\begin{array}{l}\text { Sangat } \\
\text { Mandiri }\end{array}$ & $68 \%$ \\
\hline $\begin{array}{l}\text { Mencari } \\
\text { Dukungan Sosial }\end{array}$ & $61 \%$ & $\begin{array}{l}\text { Cukup } \\
\text { Mandiri }\end{array}$ & $88 \%$ & Mandiri & $74 \%$ \\
\hline
\end{tabular}


Jurnal Ekonomi, Bisnis dan Pendidikan, 1(3), 2021, 251-262

\begin{tabular}{|c|c|c|c|c|c|}
\hline $\begin{array}{l}\text { Memeriksa } \\
\text { Catatan }\end{array}$ & $67 \%$ & $\begin{array}{l}\text { Cukup } \\
\text { Mandiri }\end{array}$ & $87 \%$ & Mandiri & $77 \%$ \\
\hline Rata-Rata & $66 \%$ & $\begin{array}{l}\text { Cukup } \\
\text { Mandiri }\end{array}$ & $88 \%$ & Mandiri & $77 \%$ \\
\hline
\end{tabular}

Table used by permission Asmaradhana, Gita Chandra. 2020. Data Hasil persentase tiap aspek kemandirian

Berdasarkan Tabel 2, dapat dilihat terjadi peningkatan untuk setiap indikator kemandirian belajar sebelum dan sesudah. Rata-rata kemandirian belajar sebelum berada pada kategori cukup mandiri, namun setelah dilakukan pembelajaran menggunakan aplikasi el-PR kemandirian belajar peserta didik meningkat berada pada kategori mandiri. Pada seluruh aspek kemandirian dapat dilihat dari perolehan rata-rata terendah yaitu pada aspek konsekuensi diri dengan persentase $68 \%$, dilihat dari indikatornya penyebab rendahnya aspek tersebut diakibatkan karena peserta didik masih kurang dalam pemberian reward atau apresiasi kepada diri sendiri setelah menyelesaikan tugas dan peserta didik masih kurang dalam membayangkan kegagalan untuk dijadikan sebagai upaya pemotivasian untuk belajar. pemberian reward memiliki peranan yang sangat penting dalam proses pembelajaran karena reward merupakan suatu bentuk motivasi belajar peserta didik yang mempengaruhi kemandirian belajar peserta didik. (Knauss dkk., 2020) (Alinurdin \& Suwahyu, 2019), (Ohmann dkk., 2018).

Tujuannya adalah setelah seseorang menerima penghargaan dalam belajar maka dia akan berusaha melakukan kegiatan belajar dengan baik, dia akan melakukan kegiatan belajarnya sendiri di luar kelas dan bahwa kecemasan akan kegagalan membuat peserta didik bersemangat untuk meningkatkan keinginan belajar.(Aguilar dkk., 2020), (Fiyanti, 2002), (Kirova dkk., 2012). Aspek kemandirian peserta didik tersebut juga memperoleh hasil aspek dengan presentasi tertinggi ialah menetapkan tujuan dan perencanaan dengan persentase 83\%. Dilihat dari indikatornya peserta didik banyak yang selalu melakukan pembuatan rangkuman sebelum ujian dan indikator kedua yaitu peserta didik sering mengerjakan soal yang mudah terlebih dahulu, pentingnya melakukan kegiatan merangkum menjadikan peserta didik terbiasa memusatkan perhatian dan menumbuhkan ingatan sehingga sangat memungkinkan bahwa proses merangkum menumbuhkan rasa mandiri di setiap peserta didik.(Al-Adeimi \& O'Connor, 2020), (Wilson \& Soblo, 2020) (Ismail, 2008).

\subsection{Analisis menggunakan aplikasi el-PR}

Analisis data uji paired sample t-test pada data kemandirian belajar peserta didik sebelum dan sesudah menggunakan aplikasi el-PR disajikan dalam tabel 4 berikut ini: 


\subsubsection{Uji Prasyarat Analisis}

\section{Hasil Uji Normalitas Data Kemandirian Belajar}

Tabel 3 Data Hasil Uji Normalitas Kemandirian Belajar

\begin{tabular}{llll}
\hline & \multicolumn{2}{l}{ Shapiro-Wilk } & Sig. \\
\cline { 2 - 4 } Kelompok & Statistic & Df & .009 \\
\hline Kemandirian Sebelum & .901 & 30 & .138 \\
Kemandirian Sesudah & .947 & 30 & . \\
\hline Table used by permission Asmaradhana, Gita Chandra. 2020. Data Hasil Uji Normalitas Kemandirian
\end{tabular}

Dikatakan normal jika nilai sig lebih dari 0.05. pada penelitian ini, untuk kemandirian sebelum dan kemandirian sesudah diberi perlakuan nilai sig masing masing adalah 0.09 dan 0.138 dimana nilai ini lebih dari 0.05 yang dapat disimpulkan bahwa residual data yang dianalisis berdistribusi normal. Sehingga analisis yang dapat dilakukan selanjutnya yaitu uji Paired sample t-test.

\subsubsection{Uji Paired Sample t-test}

Tabel 4 Data Hasil Uji Paired Sample t-test

\begin{tabular}{|c|c|c|c|c|c|c|c|c|}
\hline \multicolumn{9}{|c|}{ 95\% Confidence Interval of the Difference } \\
\hline & Mean & $\begin{array}{l}\text { Std. } \\
\text { Deviati } \\
\text { on }\end{array}$ & $\begin{array}{l}\text { Std. } \\
\text { Error } \\
\text { Mean }\end{array}$ & Lower & Upper & $\mathbf{T}$ & Df & $\begin{array}{l}\text { Sig. (2- } \\
\text { tailed) }\end{array}$ \\
\hline $\begin{array}{l}\text { Kemandiri } \\
\text { an } \\
\text { Sebelum - } \\
\text { Kemandiri } \\
\text { an } \\
\text { Sesudah }\end{array}$ & $\begin{array}{l}- \\
16.200\end{array}$ & 13.857 & 2.530 & $\begin{array}{l}- \\
21.37 \\
4\end{array}$ & -11.026 & $\begin{array}{l}- \\
6.403\end{array}$ & 29 & .000 \\
\hline
\end{tabular}

Table used by permission Asmaradhana, Gita Chandra. 2020. Data Hasil Uji Paired sample t-test Kemandirian

Diketahui bahwa nilai Sig. (2 tailed) antara kemandirian sebelum dan kemandirian sesudah adalah 0,00 dimana nilai ini kurang dari 0.05 maka sesuai dengan dasar pengambilan keputusan dalam uji paired sample t-test dapat disimpulkan bahwa H0 ditolak dan Ha diterima artinya terdapat perbedaan yang signifikan rata-rata kemandirian belajar sebelum dan sesudah menggunakan aplikasi el-PR. Hal ini menunjukan bahwa penggunaan media pembelajaran el-PR pada mata pelajaran OTKP humas dan keprotokolan efektif digunakan untuk meningkatkan kemandirian belajar peserta didik kelas XI OTP di SMK PGRI 2 Malang.

\subsubsection{Uji N-Gain}

Uji N-Gain dapat dilakukan bila diketahui ada pengaruh yang signifikan sebelum dan sesudah implementasi media pembelajaran yang dikembangkan. Uji ini dilakukan untuk mengetahui besarnya peningkatan kemandirian sebelum dan sesudah menggunakan media pembelajaran el-PR dan hasil telah tersaji dibawah ini: 


$$
\begin{aligned}
& \langle g\rangle=\frac{\text { Skor posttest }- \text { Skor pretest }}{\text { Skor ideal }- \text { Skor pretest }} \\
& <g\rangle=\frac{1969-1483}{2250-1483} \\
& \langle g\rangle=0,633
\end{aligned}
$$

Berdasarkan perhitungan diatas nilai kemandirian peserta didik sebelum dan sesudah menggunakan media pembelajaran el-PR yang dikembangkan diperoleh nilai $n$-gain sebesar 0,633 atau dapat disimpulkan bahwa besar peningkatan kemandirian peserta didik dalam kategori sedang.

\subsection{Analisis menggunakan aplikasi yang dikembangkan}

Sedangkan hasil analisis data hasil belajar peserta didik sebelum dan sesudah menggunakan aplikasi yang dikembangkan disajikan pada tabel 5 berikut ini:

Tabel 5 Data Hasil Analisis Ketercapaian KKM Peserta Didik

\begin{tabular}{llll}
\hline Pretest & & Posttest & \\
\hline Rata-Rata & Ketercapaian KKM & Rata-rata & Ketercapaian KKM \\
75,33 & $(75)$ & 86,66 & $(75)$ \\
\hline
\end{tabular}

Table used by permission Asmaradhana, Gita Chandra. 2020. Data Hasil Analisis Ketercapaian KKM Hasil Belajar

Dari pemaparan hasil perhitungan nilai posttest atau nilai sesudah menggunakan aplikasi $e l-P R$ peserta didik mencapai ketuntasan belajar. Ketuntasan hasil belajar yang dimaksud dalam penelitian ini adalah ketuntasan kognitif. Peserta didik dikatakan tuntas apabila peserta didik mendapatkan nilai lebih dari atau sama dengan kriteria ketuntasan minimal nilai 75. Peserta didik sesudah menggunakan aplikasi el-PR mencapai $100 \%$ ketuntasan belajar dengan rata-rata nilai 86,66. Berdasarkan hasil observasi dan wawancara bersama guru mata pelajaran serta peserta didik yang nilainya belum mencapai ketuntasan masalah yang dihadapi yaitu pada pembelajaran menggunakan google classroom peserta didik banyak yang terlambat dan kesusahan dalam pengaksesan materi dikarenakan keterbatasan kuota yang dimilikinya sehingga berpengaruh terhadap hasil belajar yang mereka dapatkan.

\subsubsection{Uji Prasyarat Analisis}

\section{Hasil Uji Normalitas Data Kemandirian Belajar}

Tabel 6 Data Hasil Uji Normalitas Kemandirian Belajar

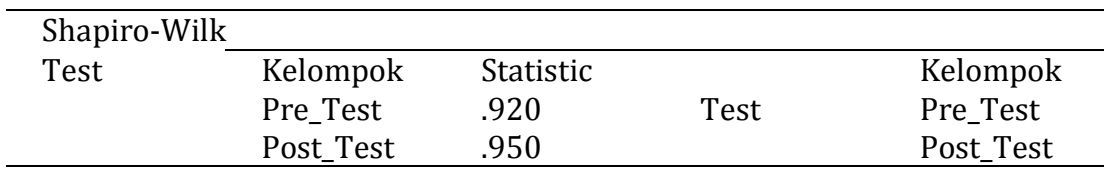

Table used by permission Asmaradhana, Gita Chandra. 2020. Data Hasil Uji Normalitas Kemandirian Belajar 
Pada penelitian ini, untuk pretest dan posttest nilai sig masing masing adalah 0.109 dan 0.140 dimana nilai ini lebih dari 0.05 yang dapat disimpulkan bahwa residual data yang dianalisis berdistribusi normal. Sehingga analisis yang dapat dilakukan selanjutnya yaitu uji Paired sample t-test

\subsubsection{Uji Paired sample t-test hasil belajar}

Tabel 7 Data Hasil Uji Paired Sample t-test

\begin{tabular}{|c|c|c|c|c|c|c|c|c|c|}
\hline \multicolumn{10}{|c|}{ 95\% Confidence Interval of the Difference } \\
\hline & & Mean & $\begin{array}{l}\text { Std. } \\
\text { Deviati } \\
\text { on }\end{array}$ & $\begin{array}{l}\text { Std. } \\
\text { Error } \\
\text { Mean } \\
\end{array}$ & Lower & Upper & $\mathbf{T}$ & $\begin{array}{l}\text { D } \\
\text { f }\end{array}$ & $\begin{array}{l}\text { Sig. (2- } \\
\text { tailed) }\end{array}$ \\
\hline Pair 1 & $\begin{array}{l}\text { Pre_Test- } \\
\text { Post_Test }\end{array}$ & $\begin{array}{l}- \\
10.00 \\
0\end{array}$ & 8.710 & 1.590 & $\begin{array}{l}- \\
13.252\end{array}$ & -6.748 & $\begin{array}{l}- \\
6.289\end{array}$ & $\begin{array}{l}2 \\
9\end{array}$ & .000 \\
\hline
\end{tabular}

Table used by permission Asmaradhana, Gita Chandra. 2020. Data Hasil uji paired sample t-test hasil belajar

Diketahui bahwa nilai Sig. ( 2 tailed) antara pretest dan posttest adalah 0,00 dimana nilai ini kurang dari 0.05 maka sesuai dengan dasar pengambilan keputusan dalam uji paired sample t-test dapat disimpulkan bahwa $\mathrm{H} 0$ ditolak dan Ha diterima artinya terdapat perbedaan yang signifikan rata-rata hasil belajar sebelum dan sesudah menggunakan aplikasi el-PR. Hal ini menunjukan bahwa penggunaan media pembelajaran el-PR pada mata pelajaran OTKP humas dan keprotokolan efektif digunakan untuk meningkatkan hasil belajar peserta didik kelas XI OTP di SMK PGRI 2 Malang.

\subsubsection{Uji N-Gain}

Uji $N$-gain dapat dilakukan bila diketahui ada pengaruh signifikan sebelum dan sesudah implementasi media pembelajaran yang dikembangkan. Uji peningkatan rata-rata dilakukan untuk mengetahui besarnya peningkatan hasil belajar sebelum menggunakan media pembelajaran el-PR dan sesudah menggunakannya.

Rumus:

$<g>=\frac{\text { Skor posttest }- \text { Skor pretest }}{\text { Skor ideal }- \text { Skor pretest }}$

$<g>=\frac{2600-2260}{3000-2260}$

$<g>=0,459$

Berdasarkan perhitungan diatas nilai hasil belajar sebelum dan sesudah menggunakan media pembelajaran el-PR yang dikembangkan diperoleh nilai $n$-gain sebesar 0,459 atau dapat disimpulkan bahwa peningkatan hasil belajar peserta didik dalam kategori sedang, Hasil penelitian ini relevan dengan penelitian yang dilakukan oleh sejumlah peneliti diantaranya (Damayanti, 2018) yang menunjukan bahwa dengan penggunaan media berbasis ispring suite dapat meningkatkan hasil belajar. Penelitian (Himmah, 2017) juga menunjukan hasil bahwa sesudah menggunakan media pembelajaran berbasis ispring suite hasil peserta didik meningkat dibandingkan sebelum menggunakan media tersebut. 


\section{Simpulan}

Penelitian dan pengembangan ini menghasilkan media pembelajaran berbasis ispring suite 9 untuk meningkatkan kemandirian belajar dan hasil belajar peserta didik pada mata pelajaran Otomatisasi Tata Kelola Humas dan Keprotokolan kelas XI OTKP di SMK PGRI 2 Malang. Media Pembelajaran ini bernama el-PR (elektronik learning Public Relation) dan dapat diunduh secara gratis melalui link: shorturl.at/ny/BW2.

Media pembelajaran pada penelitian ini telah dinyatakan 'Sangat Valid' dan layak digunakan dalam pembelajaran Otomatisasi Tata Kelola Humas dan Keprotokolan melalui validasi ahli media, validasi ahli materi serta penilaian penggunaan pada uji coba kelompok kecil. Selain itu, aplikasi el-PR ini terbukti efektif digunakan untuk meningkatkan kemandirian belajar dan hasil belajar pada uji coba kelompok besar berdasarkan uji paired sample t-test. Aplikasi ini juga memungkinkan pembelajaran kapanpun dan dimanapun, bahkan dapat dioperasikan secara mandiri secara offline sehingga dapat menjadi solusi untuk menunjang pembelajaran jarak jauh khususnya pada saat pandemi covid-19 ini.

Aplikasi el-PR hanya berfokus pada beberapa kompetensi dasar dan terbatas pada sistem operasi android, sehingga diharapkan peneliti selanjutnya mengembangkan media pembelajaran pada sistem operasi lainnya seperti IOS serta lebih mengembangkan pada hasil evaluasi yaitu menyajikan hasil evaluasi pembelajaran pada satu file rekapan tabulasi nilai.

\section{Ucapan Terima Kasih}

Penulis mengucapkan terimakasih kepada Universitas Negeri Malang dan SMK PGRI 2 Malang yang telah memfasilitasi dan memberi izin kepada peneliti untuk melakukan kegiatan penelitian dan pengembangan ini.

\section{Daftar Rujukan}

Aguilar, S.J., Karabenick, S.A., Teasley, S.D., Baek, C., (2020). Associations Between Learning Analytics Dashboard Exposure And Motivation And Self-Regulated Learning. Comput. Educ. 162, 104085. Https://Doi.Org/10.1016/J.Compedu.2020.104085

Al-Adeimi, S., O'connor, C., (2020). Exploring The Relationship Between Dialogic Teacher Talk And Students' Persuasive Writing. Learn. Instr. 71, 101388. Https://Doi.Org/10.1016/J.Learninstruc.2020.101388

Alfiyansah, R., (2016). Penggunaan Media Pembelajaran I-Spring Presenter Untuk Meningkatkan Motivasi Belajar Dan Hasil Belajar Pada Mata Kuliah Keperawatan Dasar Nutrisi. Pedagogia 14(2). Https://Doi.Org/10.17509/Pedagogia.V14i2.3886

Alinurdin, A., \& Suwahyu, S. (2019). Mengembangkan Kemandirian Belajar dalam Pembelajaran PPKn melalui Reward dan Punishment. Jurnal Pendidikan Kewarganegaraan, 6(1), 13-24. Https://Doi.Org/10.32493/Jpkn.V6i1.Y2019.P13-24

Arikunto, S., (2010). Prosedur Penelitian Suatu Pendekatan Praktik. Rineka Cipta, Jakarta.

Ariyanti, D., Mustaji, Harwanto, (2020). Multimedia Interaktif Berbasis Ispring Suite 8. J. Educ. Dev. 8, 381-381.

Arulogun, O.T., Akande, O.N., Akindele, A.T., Badmus, T.A., (2020). Survey Dataset On Open And Distance Learning Students' Intention To Use Social Media And Emerging Technologies For Online Facilitation. Data Brief 31, 105929. Https://Doi.Org/10.1016/J.Dib.2020.105929

Azzahra, N.F., (2020). Addressing Distance Learning Barriers In Indonesia Amid The Covid-19 Pandemic.

Bali, M.M.E.I., (2019). Implementasi Media Pembelajaran Berbasis Teknologi Informasi Dan Komunikasi Dalam Distance Learning. Tarbiyatuna Kaji. Pendidik. Islam 3, 29-40. Https://Doi.Org/10.29062/Tarbiyatuna.V3i1.198

Damayanti, E., Rustiyarso, R., Rahmatika, I., (2018). Efektivitas Penggunaan Media Ispring Suite 8 Terhadap Hasil Belajar Sejarah Kelas X Sman 5 Pontianak. J. Pendidik. Dan Pembelajaran Khatulistiwa 7. 
Dasmo, D., Lestari, A.P., Alamsyah, M., (2020). Peningkatan Hasil Belajar Fisika Melalui Penerapan Media Pembelajaran Interaktif Berbasis Ispring Suite 9. Sinasis Semin. Nas. Sains 1.

Deng, H., Chen, W., Shen, Q., Ma, A.J., Yuen, P.C., Feng, G., (2020). Invariant Subspace Learning for Time Series Data Based On Dynamic Time Warping Distance. Pattern Recognit. 102, 107210. Https://Doi.Org/10.1016/J.Patcog.2020.107210

Fajriah, U.N., Churiyah, M., (2016). Utilizing Instructional Media for Teaching Infrastructure Administration. J. Educ. Pract. 7(6), 100-111.

Fitri, M., (2020). Pengaruh Emergency Remote Learninguntuk Melihat Motivasi Belajar Anak Usia Dini. Child Educ. J. Volume 2, 68-82.

Fiyanti, R.A., (2002). Hubungan Antara Kecemasan Akan Kegagalan Dengan Motivasi Bersaing Pada Siswa Program Unggulan Di Smu Muhammadiyah I Gresik. J. Inst. Teknol. Bdg.

Greene, K., Ray, A.E., Choi, H.J., Glenn, S.D., Lyons, R.E., Hecht, M.L., (2020). Short Term Effects Of The Real Media E-Learning Media Literacy Substance Prevention Curriculum: An Rct Of Adolescents Disseminated Through A Community Organization. Drug Alcohol Depend. 214, 108170. Https://Doi.Org/10.1016/J.Drugalcdep.2020.108170

Herbst, P., Chazan, D., (2015). Studying Professional Knowledge Use In Practice Using Multimedia Scenarios Delivered Online. Int. J. Res. Method Educ. 38, 272-287. Https://Doi.Org/10.1080/1743727x.2015.1025742

Himmah, F., (2017). Pengembangan Media Multimedia Interaktif Menggunakan Ispring Suite 8 Pada Sub Materi Zat Aditif Untuk Meningkatkan Hasil Belajar Peserta Didik Smp Kelas Viii. Pensa J. Pendidik. Sains Vol 5 (2).

Hussein, E., Daoud, S., Alrabaiah, H., Badawi, R., (2020). Exploring Undergraduate Students' Attitudes Towards Emergency Online Learning During Covid-19: A Case From The Uae. Child. Youth Serv. Rev. 119, 105699. Https://Doi.Org/10.1016/J.Childyouth.2020.105699

Ismail, Muh.I., (2008). Pemberian Rangkuman Sebagai Strategi Pembelajaran. J. Form. 11 48-57.

Kirova, S., Petkovska, B., Koceva, D., (2012). Investigation Of Motivation And Anxiety In Macedonia While Learning English As A Second/Foreign Language. Procedia - Soc. Behav. Sci., 4th World Conference On Educational Sciences (Wces-2012) 02-05 February 2012 Barcelona, Spain 46, 3477-3481. Https://Doi.Org/10.1016/J.Sbspro.2012.06.088

Knauss, Z.T., Filipovic, M., Smith, K.A., Queener, M.M., Lubera, J.A., Bolden-Hall, N.M., Smith, J.P., Goldsmith, R.S., Bischoff, J.E., Miller, M.K., Cromwell, H.C., (2020). Effort-Reward Balance And Work Motivation In Rats: Effects Of Context And Order Of Experience. Behav. Processes 181, 104239. Https://Doi.Org/10.1016/J.Beproc.2020.104239

Kramer, C., König, J., Strauß, S., Kaspar, K., (2020). Classroom Videos Or Transcripts? A Quasi-Experimental Study To Assess The Effects Of Media-Based Learning On Pre-Service Teachers' Situation-Specific Skills Of Classroom Management. Int. J. Educ. Res. 103, 101624. Https://Doi.Org/10.1016/J.Ijer.2020.101624

Kumar, J.A., Muniandy, B., Yahaya, W.A.J.W., (2019). Exploring The Effects Of Emotional Design And Emotional Intelligence In Multimedia-Based Learning: An Engineering Educational Perspective. New Rev. Hypermedia Multimed. 25, 57-86. Https://Doi.Org/10.1080/13614568.2019.1596169

Kusuma, J.W., Jefri, U., Surnani, E., Pratiwi, I., Kurniawan, E., (2020). Pelatihan Penggunaan Aplikasi Classdojo Sebagai Upaya Peningkatan Pembelajaran Jarak Jauh Bagi Guru Sd It Bina Bangsa Di Era Kenormalan Baru. Jpkm-Aphelion J. Pengabdi. Kpd. Masy. - Aphelion 1, 57-67.

Kusumarini, A., Bangunan, P., (2020). Implikasi Media Pembelajaran E-Learning Terhadap Pembelajaran Jarak Jauh (Pjj).

Nudiya, R., Prima, A., Syahrul, R., (2019). Penerapan Model Trait Treatment Interaction Berbatuan Aplikasi Ispring Suite Untuk Mempengaruhi Literasi Sains Di Sman 16 Padang. Nat. Sci. J. Penelit. Bid. Ipa Dan Pendidik. Ipa 5 (2). Https://Doi.Org/10.15548/Nsc.V5i2.1089

Ohmann, H.A., Kuper, N., Wacker, J., (2018). Left Frontal Anodal Tdcs Increases Approach Motivation

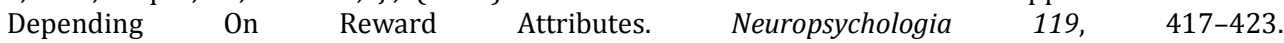
Https://Doi.Org/10.1016/J.Neuropsychologia.2018.09.002

Panigrahi, R., Srivastava, P.R., Sharma, D., (2018). Online Learning: Adoption, Continuance, And Learning Outcome-A Review Of Literature. Int. J. Inf. Manag. 43, 1-14. Https://Doi.Org/10.1016/J.Ijinfomgt.2018.05.005 
Parsazadeh, N., Ali, R., Rezaei, M., (2018). A Framework For Cooperative And Interactive Mobile Learning To Improve Online Information Evaluation Skills. Comput. Educ. 120, 75-89. Https://Doi.Org/10.1016/J.Compedu.2018.01.010

Pohan, A., E., (2020). Konsep Pembelajaran Daring Berbasis Pendekatan Ilmiah. Cv: Sarnu Untung, Jawa Tengah.

Qazi, A., Naseer, K., Qazi, J., Alsalman, H., Naseem, U., Yang, S., Hardaker, G., Gumaei, A., (2020). Conventional To Online Education During Covid-19 Pandemic: Do Develop And Underdeveloped Nations Cope Alike. Child. Youth Serv. Rev. 119, 105582. Https://Doi.Org/10.1016/J.Childyouth.2020.105582

Rafiq, M., (2017). Pengembangan Media Pembelajaran Matematika Berbasis Pendekatan Saintifik Dengna Powerpoint Ispring Suite Pada Materi Perbandingan Di Kelas Viii Smp Negeri 1 Kota Jambi. J. Pendidik. Mat.

Ramdhani, M.A., Muhammadiyah, H., (2015). The Criteria Of Learning Media Selection For Character Education In Higher Education. Presented At The International Conference Of Islamic Education In Southeast Asia, Malang, Indonesia, Pp. 174-182.

Sahronih, S., Purwanto, A., Sumantri, M.S., (2019). The Effect Of Interactive Learning Media On Students' Science Learning Outcomes, In: Proceedings of The 2019 7th International Conference On Information And Education Technology, Iciet 2019. Association For Computing Machinery, New York, Ny, Usa, Pp. 2024. Https://Doi.Org/10.1145/3323771.3323797

Sari, M.P., Ridwan, (2020). Interactive Multimedia Development Using Ispring Suite 9 Application In Natural Sciences Learning Of Ix Grade In Junior High School | Sari | International Journal Of Progressive Sciences And Technologies.

Sholihin, M., Sari, R.C., Yuniarti, N., Ilyana, S., (2020). A New Way Of Teaching Business Ethics: The Evaluation Of Virtual Reality-Based Learning Media. Int. J. Manag. Educ. 18, 100428. Https://Doi.Org/10.1016/J.Ijme.2020.100428

Siregar, A. C., Adisaputera, A., \& Yus, A. (2020). The Development of Interactive Media Assisted by Macromedia Flash to Improve the Ability of Understanding the Fiction Story Information in Elementary School Students. Budapest International Research and Critics in Linguistics and Education (BirLE) Journal, 3(2), 1200-1208.. Https://Doi.Org/10.33258/Birle.V3i2.1053

Sufian, A., Ghosh, A., Sadiq, A.S., Smarandache, F., (2020). A Survey On Deep Transfer Learning To Edge Computing For Mitigating The Covid-19 Pandemic. J. Syst. Archit. 108, 101830. Https://Doi.Org/10.1016/J.Sysarc.2020.101830

Suparti, (2016). Metode Penelitian Pengembangan Inovasi Pembekalan Beserta Contoh Proposal, 1. Universitas Negeri Malang, Malang.

Wang, H., Yin, Y., Hui, X.Y., Bai, J.Q., Qu, Z.G., (2020). Prediction Of Effective Diffusivity Of Porous Media Using Deep Learning Method Based On Sample Structure Information Self-Amplification. Energy Ai 2, 100035. Https://Doi.Org/10.1016/J.Egyai.2020.100035

Wijaya, T.T., Ying, Z., Cunhua, L., Zulfah, Z., (2020). Using Vba Learning Media To Improve Students' Mathematical Understanding Ability. J. Educ. 2, 245-254. Https://Doi.Org/10.31004/Joe.V2i3.314

Wilson, J. A., \& Soblo, H. (2020). Transfer and transformation in multilingual student writing. Journal of English for Academic Purposes, 44, 100812.. 44, 100812. Https://Doi.Org/10.1016/J.Jeap.2019.100812

Yang, X. P., Liu, X. X., Guo, Y. H., \& Wang, S. J. (2012). Optimization and Application of Multimedia Teaching Means of Specialized Courses in Engineering. Energy Procedia, 17, 1878-1884. Https://Doi.Org/10.1016/J.Egypro.2012.02.326

Yektyastuti, R., Ikhsan, J., (2016). Pengembangan Media Pembelajaran Berbasis Android Pada Materi Kelarutan Untuk Meningkatkan Performa Akademik Siswa Sma. J. Inov. Pendidik. Ipa 2, 88-99. Https://Doi.Org/10.21831/Jipi.V2i1.10289

Yeldham, M., Gao, Y.-J., (202). Examining Whether Learning Outcomes Are Enhanced When L2 Learners' Cognitive Styles Match Listening Instruction Methods. System $97 \quad 102435$. Https://Doi.Org/10.1016/J.System.2020.102435 